\title{
Efficacy of different fungicides for management of early blight disease of potato
}

\author{
S. Murmu', S. Dey ${ }^{2}$ and A. Chakraborty ${ }^{3}$ \\ ${ }^{1}$ Survey Selection and Mass Production of Nodule Bacteria, Directorate of Research, Bidhan Chandra Krishi \\ Viswavidyalaya, Mohanpur, Nadia-741252 (West Bengal), INDIA \\ ${ }^{2}$ Department of Plant Pathology, Bidhan Chandra Krishi Viswavidyalaya, Mohanpur, Nadia-741252 (West Bengal), \\ INDIA \\ ${ }^{3}$ AICRP on Potato, Directorate of Research, Bidhan Chandra Krishi Viswavidyalaya, Kalyani, Nadia - 741235, (West \\ Bengal), INDIA \\ *Corresponding author. E-mail: saharmurmu@gmail.com
}

Received: February 10, 2016; Revised received: December 15, 2016; Accepted: January 26, 2017

\begin{abstract}
The early blight of potato may be controlled by using bio-control agents and plant extracts but not effectively and rapidly. But using of chemical fungicides the disease can be controlled easily and losses of yield will be reduced compare to above mentioned both control measures. Keeping this in mind an experiment was conducted to test the efficacy of seven different fungicides (difenoconazole, propiconazole, hexaconazole, propineb $61 \%+$ iprovalicarb 5.25\%, propineb, carbendazim and metalaxyl $8 \%+$ mancozeb 64\%) for controlling early blight of potato under in vivo as well as in vitro condition. These antifungal compounds were applied 3 times at 7 days interval after first appearance of the disease in the field. Highest per cent disease reduction $(57.88 \%)$ and highest yield of tuber $(27.03 \mathrm{t} / \mathrm{ha})$ was recorded in plot sprayed with propiconazole @1 ml/lit followed by propineb and propineb 61\% + iprovalicarb $5.25 \%$, with per cent disease reduction $55.98 \%, 51.90 \%$ and yield 26.30 t/ha and 24.53 t/ha respectively. Simultaneously In vitro efficacy of these fungicides were also tested against Alternaria solani where propiconazole and propineb exhibited highest percent inhibition(100\%) in radial growth and in case of spore germination inhibition in spite of these two fungicides difenoconazole, hexaconazole and propineb $61 \%+$ iprovalicarb $5.25 \%$ exhibit same result i.e. $100 \%$ inhibition compared to control as well as other treatments. Therefore it may be suggested that propiconazole and propineb can be used successfully in controlling of this disease.
\end{abstract}

Keywords: Early Blight, Fungicide, Management, Potato

\section{INTRODUCTION}

The potato (Solanum tuberosum) is one of the most important vegetable crops in the world, belonging to the family Solanaceae and is an important starchy food crop in both sub-tropical and temperate regions. Even in tropical regions it is widely grown during winter season. Potato ( $S$. tuberosum) is a native of South America(Hijmans and Spooner, 2001). In India the potato has been cultivated since its introduction in the early part of the $17^{\text {th }}$ century. In India potato is grown in almost all the states under diverse climatic conditions except Kerala and $82 \%$ of potatoes are grown in plains during the short winter days from October to March. Potato is the most popular crop in West Bengal next to cereals (Chakraborty, 2012). Potato plants are subjected to attack by numerous diseases wherever the crop is grown. Among them, early blight disease of potato caused by Alternaria solani (Ellis and Martin) Jones and Grout is also a major cause of concern in potato production at present. The disease causes losses to crop productivity in the field and to tuber quality in storage. In stored condition, potato losses may be sub- stantial and reach $80 \%$ of tubers, affected by early blight lesions. Average annual yield loss of potato due to this disease is approximately $75 \%$ of the total production depending upon the nature of the disease, weather condition and type of variety grown (Dey and Chakraborty, 2012). In West Bengal, the disease appears at regular basis for which management of the disease through various chemical fungicides is necessary (Dey and Chakraborty, 2012).Therefore, the present investigation was carried out to find out the effective chemical fungicides for controlling of early blight disease of potato under field condition as well as in in vitro condition using poisoned food technique and spore germination inhibition technique in West Bengal.

\section{MATERIALS AND METHODS}

The experiment was conducted during the Rabi season at Adisaptagram Block Seed Farm, Hooghly, West Bengal during 2012-2013 and 2013-2014 crop seasons. The field experiment was laid out in randomised block design (RBD) with 8 treatments and 4 replications where each plot size is about $3 \mathrm{~m} \times 2 \mathrm{~m}$. The chemical fertilizers, N, $\mathrm{P}_{2} \mathrm{O}_{5}$ and $\mathrm{K}_{2} \mathrm{O}$ was applied @ $200 \mathrm{~kg} / \mathrm{ha}$, 
$150 \mathrm{~kg} / \mathrm{ha}$ and $150 \mathrm{~kg} / \mathrm{ha}$ respectively. The $50 \%$ of nitrogen and full dose of $\mathrm{P}_{2} \mathrm{O}_{5}$ and $\mathrm{K}_{2} \mathrm{O}$ were applied during planting and rest $50 \%$ nitrogen was applied as top dressing during earthing up.

The percent disease incidence and intensity of early blight of potato were recorded at 7 days interval after first appearance of the disease and fungicides were sprayed after taking each observation with their recommended dose such as carbendazim, propineb, metalaxyl 8\% + mancozeb 64\%, and propineb 61\% + iprovalicarb 5.25\%, @1 g/lit of water and hexaconazole, propiconazole, and difenoconazole@ $1 \mathrm{ml} /$ lit of water.

The percent disease incidence of the early blight of potato was calculated by the following formula. The disease severity of early blight of potato was recorded following 0-5 scale (Sharma and Kolte,1994) as shown in Table 1.For the study of disease intensity 17 plants per plot was randomly selected and 1 upper leaf, 1 middle leaf and 1 lower leaf of each plant were selected and percentage of infected area of each leaf was recorded at weekly interval and percent disease index (PDI) or disease intensity of this disease was calculated using the formula (McKinney, 1923). Pooled data of two years is presented in Table 2 regarding disease incidence and disease intensity.

The in vitro efficacy of the test fungicides were also carried out by spore germination inhibition and growth inhibition following poisoned food technique (Vincent, 1947).In case of poisoned food technique (Falck, 1907) the inhibitory activity of each treatment was expressed as the percent growth inhibition which was calculated using the following formula (Pandey et al., 1982):

\section{RESULTS AND DISCUSSION}

The results of the experiment under field condition as well as in vitro condition regarding management of early blight of potato caused by A.solani are presented here.

Management studies of early blight of potato under field condition: It is evident from the result presented in table (2) that treatment $\mathrm{T}_{6}$ i.e. propiconazole @ 1 $\mathrm{ml} /$ lit exhibited best result in terms of per cent disease incidence $(44.00 \%)$ and per cent disease intensity $(7.53 \%)$ at 77 DAP as compared to control treatment $\left(\mathrm{T}_{8}\right)$ where per cent disease incidence and intensity were $88.67 \%$ and $17.88 \%$ respectively. The overall disease reduction was $57.88 \%$ over control which was also highest compared to all other treatments. Moreover, the total tuber yield was also highest i.e. $27.03 \mathrm{t} / \mathrm{ha}$ in this treatment. Among all other treatments, the next best result was obtained in treatment $\mathrm{T}_{3}$, where propineb (a) 1g/lit resulted $55.98 \%$ disease reduction over control treatment with total tuber yield $26.30 \mathrm{t} / \mathrm{ha}$. This was followed by propineb $61 \%+$ iprovalicarb $5.25 \%,\left(\mathrm{~T}_{7}\right)$ with incidence and intensity per cent $45.33 \%$ and 8.60
$\%$ respectively at $77 \mathrm{DAP}$. In this treatment percent disease reduction over control was $51.90 \%$ and total tuber yield $24.53 \mathrm{t} / \mathrm{ha}$ respectively. These findings are also in agreement with Aruna kumara et al. (2010) who reported that effective control of the disease is possible with fungicidal application of mancozeb $(0.2 \%)$ or propiconazole $(0.1 \%)$.

Efficacy of fungicides on growth inhibition of $\boldsymbol{A}$. solani in in vitro condition by poisoned food technique: It is evident from the table (3) that $100 \%$ growth inhibition over control was observed in case of propiconazole $\left(\mathrm{T}_{6}\right)$ and propineb $\left(\mathrm{T}_{3}\right)$ at $200 \mathrm{ppm}$ concentration. These were followed by propineb $61 \%$ + iprovalicarb 5.25\%, difenoconazole, hexaconazole and metalaxyl $8 \%+$ mancozeb $64 \%$ where per cent growth inhibition over control were observed as 79.29, 75.73, 67.07 and $56.72 \%$ respectively. But it was observed that propiconazole $\left(\mathrm{T}_{6}\right)$ and propineb $\left(\mathrm{T}_{3}\right)$ showed same result $(100 \%$ growth inhibition) at 100 ppm concentration also where other fungicides showed comparatively less growth inhibition, similar trend was found at the $50 \mathrm{ppm}$ concentration of all the test fungicides. These findings are also in line with Meena and Rajamani (2014) who also reported that propiconazole $(0.1 \%)$ was effective in inhibition $(54.7 \%)$ of radial growth of $A$. solani. Herle and Kamanna (2014) reported that propiconazole (0.1\%) and hexaconazole $(0.1 \%)$ were effective (100\%) against $A$. solani in in vitro condition.

Efficacy of fungicides on inhibition of conidial germination of $A$. solani in in vitro condition: From the table 4 , it is evident that at $50 \mathrm{ppm}$ concentration only propineb, propiconazole and propineb $61 \%+$ iprovalicarb $5-25 \%$ exhibited $100 \%$ inhibition in conidial germination. But at 100 and 200ppm concentration propineb, difenoconazole, hexaconazole, propiconazole and propineb $61 \%$ + iprovalicarb 5-25\% exhibited $100 \%$ inhibition in conidial germination where as carbendazim and metalaxyl $81 \%$ + mancozeb $64 \%$ at 100 and 200 ppm concentration exhibited 45.72, 82.06\% and 56.48, 89.36\% inhibition in conidial germination. These findings are also in agreement with Measta et al,(2009) who reported that Propiconazole $(0.15 \%)$ and hexaconazole $(0.15 \%)$ were effective in $95.35 \%$ and $94.34 \%$ spore germination inhibition of Alternaria sp.

Table 1. Rating scale (0-5) for measuring disease intensity of early blight of potato.

\begin{tabular}{cl}
\hline Rating & Description \\
\hline 0 & Free from infection (no visible symptoms). \\
1 & $1-10 \%$ leaf area damaged. \\
2 & $10.1-20 \%$ leaf area damaged. \\
3 & $20.1-50 \%$ leaf area damaged. \\
4 & $50.1-75 \%$ leaf area damaged. \\
5 & Above $75 \%$ leaf area damaged. \\
\hline
\end{tabular}


S. Murmu et al. / J. Appl. \& Nat. Sci. 9 (1): 280 - 285 (2017)

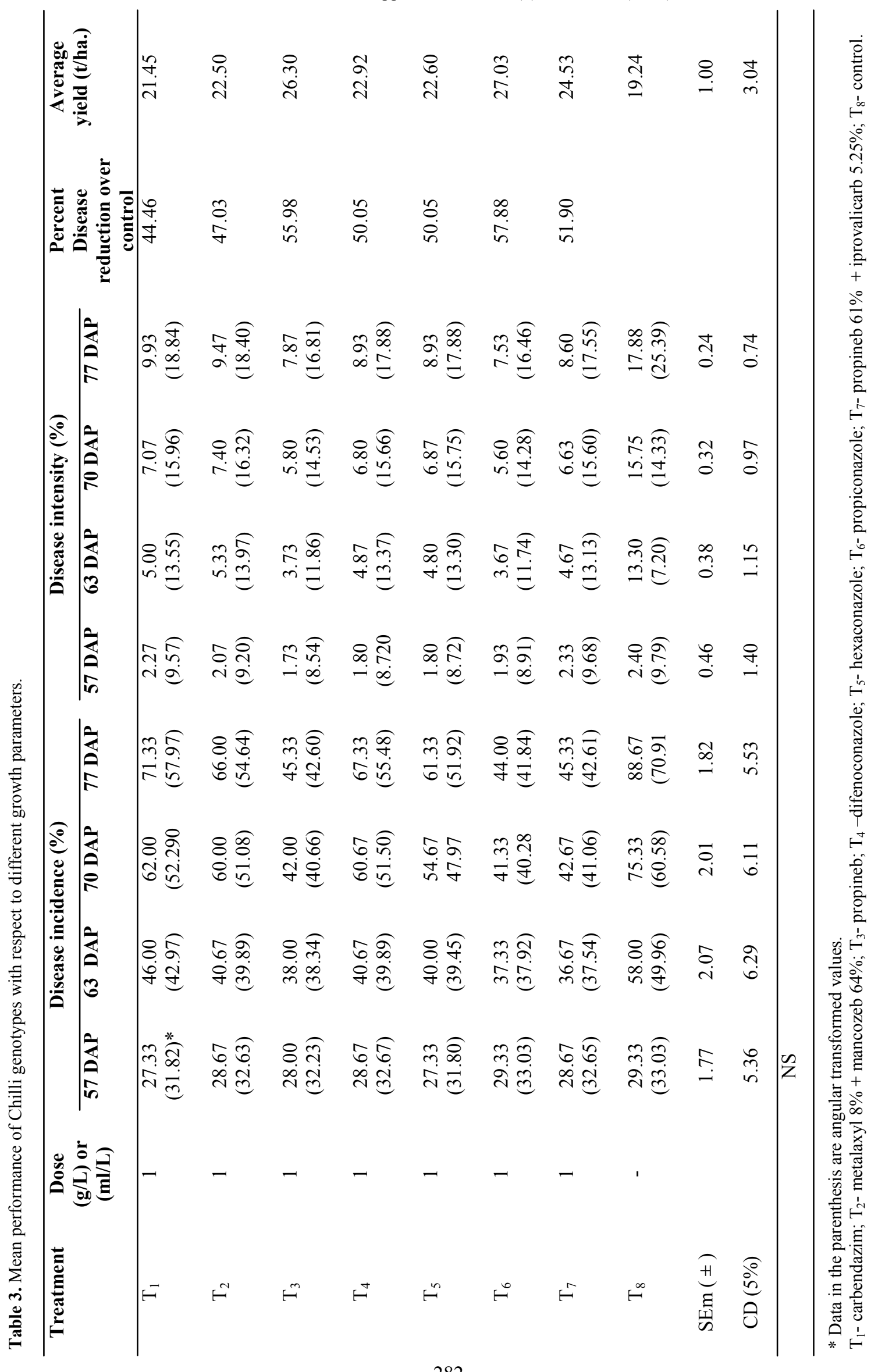


S. Murmu et al. / J. Appl. \& Nat. Sci. 9 (1): 280 - 285 (2017)

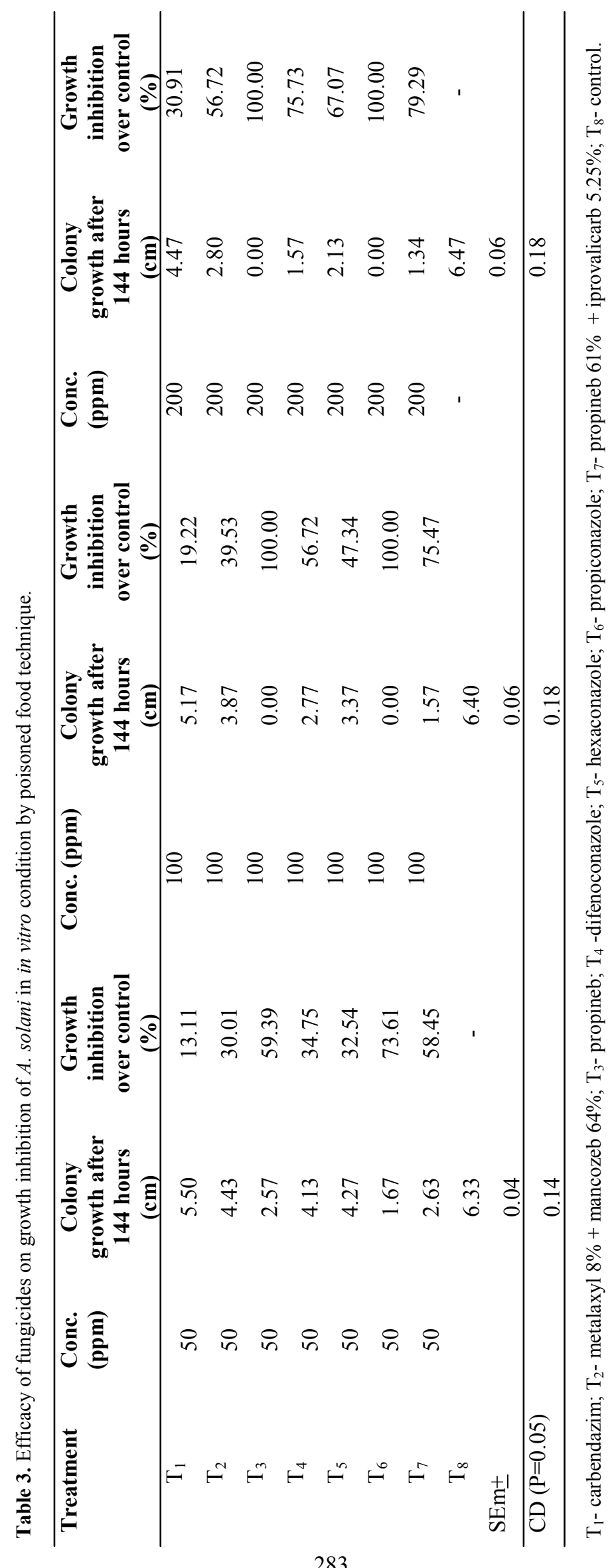


S. Murmu et al. / J. Appl. \& Nat. Sci. 9 (1): 280 - 285 (2017)

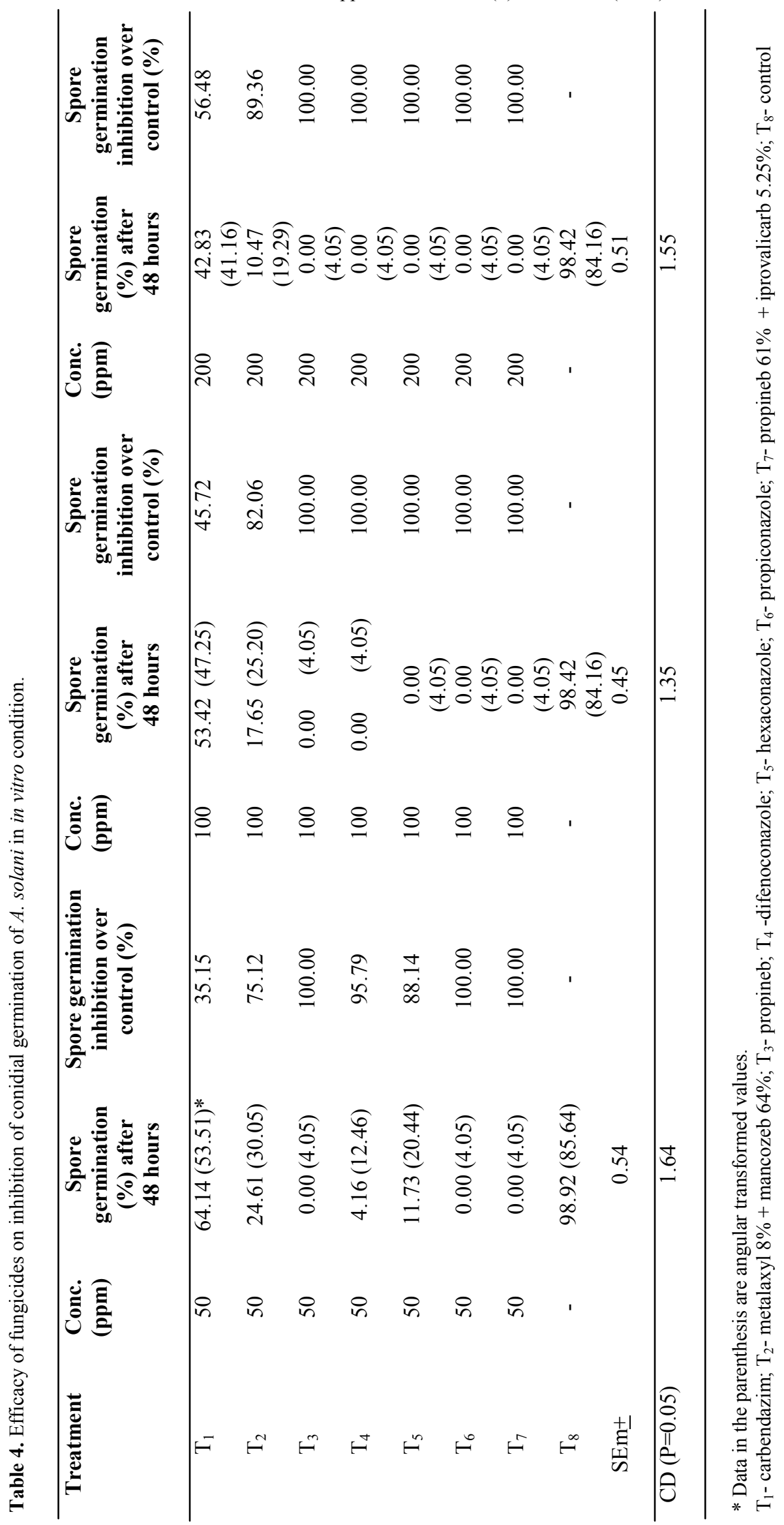




\section{Conclusion}

The present investigation concluded that propiconazole was the best $(57.88 \%)$ in management of early blight disease of potato over control and also in inhibition $(100 \%)$ of radial growth in in vitro condition among another fungicides at same concentration (200ppm). Therefore, it may be concluded that propiconazole may be used for effective management of early blight disease of potato in field condition

\section{REFERENCES}

Arunakumara. K.T., Kulkarnai. M.S., Thammaiah. N., and Hegde. Y.(2010). Fungicidal management of early blight of tomato. Ind. Phytopath.63 (1): 96-97.

Chakraborty, A. (2012). Prevalence of diseases of potato in Indo-Gangetic plains of West Bengal. J. Mycopathol. Res., 50 (1):117-119

Dey, S. and Chakraborty, A. (2012). Varietal reaction against early blight of potato in plains of West Bengal. J. Crop Weed., 8 (1): 181-183.

Falck, R. (1907). Wachtumgesetze, wachstum Laktorehnund temperature wertder holzersterenden. Myceture. 32: 38-39

Hijmans, R.J. and Spooner, D.M. (2001). Geographic dis-tribution of wild potato species. Am. J. Bot., 88 (11):
2101-12

Herle.G.S., and Kamanna. B. C. (2014). In vitro and in vivo evaluation of fungicides against early blight of potato caused by Alternaria solani (Ellis and Martin) Jones and Grout. Plant Arch., 14 (2). 971-975

McKinney, H.H. (1923). Influence of soil temperature and moisture on infection of wheat seedling by Helminthosporium sativum. J.Agril. Res. 26: $195-217$

Meena, B.,and Rajamani, K. (2014).Management of leaf early blight disease in Solanum nigram using fungicides and biocontrol agents. Eur.J. Mol. Biol. Biochem.1 (3):88-90

Measta, R.K., Benagi, V.I., Kulkarni, S., and Shankergoud, I. (2009). In vitro evaluation of fungicides and plant extracts against Alternaria helianthi causing blight of sunflower. Karnataka J. Agric. Sci..22(1) : (111-114)

Pandey, D.K., Tripathi, N.N., Tripathi, R.O. and Dixit, S.N. (1982). Fungitoxic and phyototoxic properties of essential oil of Phylissauvolensis. PfkrankhPfschuz. 89: 334-346

Sharma ,S.R. and Kolte, S.G.(1994). Effect of soil applied NPK fertilizers on severity of black spot disease (Alternaria brassicae) and yield of oil seed rape. Plant soil, 167:313-320

Vincent, J.M., (1947). Distortion of fungal hyphae in the presence of certain inhibitors. Nature. 159: 239-241 